\title{
Effect of some essential oils on the growth of Scenedesmus subspicatus
}

\section{Bazı uçucu yağların Scenedesmus subspicatus büyümesi üzerine etkileri}

\author{
Muhammet Ali Karaaslan (D) \\ Ege University, Faculty of Fisheries, Hydrobiology Department, Ecotoxicology Lab, Ege University Bornova - İzmir, Turkey \\ muhammet.ali.karaaslan@ege.edu.tr
}

Received date: 14.02 .2018

Accepted date: 02.04 .2018

\section{How to cite this paper:}

Karaaslan, M A. (2018). Effect of some essential oils on the growth of Scenedesmus subspicatus. Ege Journal Fisheries and Aquatic Sciences, 35(2), 195-198. DOI:10.12714/egejfas.2018.35.2.13

\begin{abstract}
Due to the essential oils known as having great antimicrobial activities, they have been heavily used by several industries such as medical, cosmetics, food and agriculture since long past of human history. The essential oils are the secondary metabolite of aromatic plants and about $1 / 10^{\text {th }}$ of known 3000 essential oils are widely used. They reached to the environment after used in any product and behave as xenobiotics especially in aquatic environment. Although, essential oils are natural plant extracts could be potential candidates for pest control or used any other purposes possible environmental impact needs to be investigation. In order to investigate the environmental impact of some essential oils such as rosemary oil, tea tree oil, wheat germ oil, grape seed oil, thyme oil and eucalyptus oil, Scenedesmus subspicatus were selected for testing as one of the primary producer species since they are the first trophic level of food chain. This test is approved as OECD 201 Algal Growth Inhibition test. As the result of this investigation, algal growth inhibition assays of tested oils did not show severe effects on the population growth of algae. The estimated $\mathrm{EC}_{50}$ values were 15.6, 35.09, 65.03, 100.17, 201.02, $414.47 \mathrm{mg} / \mathrm{L}$ for rosemary oil, wheat germ oil, tea tree oil, thyme oil, eucalyptus oil and grape seed oil respectively.
\end{abstract}

Keywords: Essential oils, Algal Growth Inhibition Assay, aquatic toxicity, Scenedesmus subspicatus, Phytotoxicity

Öz: Güçlü antimikrobiyal etkisi bilinen uçucu yağlar; tıp, kozmetik, gıda ve tarım gibi birçok alanda uzun yıllardan beri yoğun bir şekilde kullanılmaktadır. Aromatik bitkilerin ikincil metabolitleri olan uçucu yağların 3000 çeșidinden $1 / 10$ ' u yaygın kullanıma sahiptir. Içeriğinde bulunan maddelerin kullanımı ile çevreye salınmakta ve özellikle sucul ortamlarda ksenobiyotik gibi davranmaktadır. Uçucu yağlar bitkilerden elde edilen doğal maddeler olarak zararlı mücadelesinde kullanııalar da olası çevresel etkilerinin araştırı ması gerekmektedir. Uçucu yağlardan; biberiye yağı, çay ağacı yağı, buğday yağı, üzüm çekirdeği yağı, kekik yağı ve okaliptus yağının çevresel etkilerinin belirlenmesi için besin zincirinin ilk basamağındaki üreticilerden olan Scenedesmus subspicatus kullanılarak OECD 201 Algal Büyüme İnhibisyon testi olarak bilinen testler uygulanmıştır. Denemelerin sonunda test edilen uçucu yağların alg popülasyonunun büyümesi üzerinde ağır olumsuz etkilerinin olmadığı görülmüştür. Biberiye yağı, Çay ağacı yağı, buğday yağı, üzüm çekirdeği yağı̆ı, kekik yağı ve okaliptus yağının $\mathrm{EC}_{50}$ değerleri sırasıyla; $15,6,35,09,65,03$, $100,17,201,02,414,47 \mathrm{mg} / \mathrm{L}$ olarak hesaplanmıştır.

Anahtar kelimeler: Uçucu yağlar, Algal Büyüme İnhibisyon Testi, sucul toksisite, Scenedesmus subspicatus, fitotoksisite

\section{INTRODUCTION}

Recently, essential oils are popular products as consumers search for alternatives to some chemicals that are toxic both to their bodies and to the environment (Anonymous, 2017a). Essential oils are used in four main purpose commercially: as pharmaceuticals, as flavour enhancers in many food products, as odorants in fragrances, and as insecticides (Geetha and Roy, 2014). Anonymous (2017a) reviewed that global essential oil market is expected to reach $\$ 11.67$ billion by 2022 (Anonymous, 2017a). Due to the essential oils known as having great antimicrobial activities, they have been heavily used by several industries such as medicinal, cosmetics, food and agriculture since long past of human history like $1500 \mathrm{BC}$ as first recorded blend in Egypt. Recently, more than 3000 kind of essential oil have been produced but about 300 of them are widely used for several purposes (Arslan et al., 2015). Some of the natural plant oils contain a wide range of chemical ingredient which can interrupt biological life cycle of animals such as insects.

As the demands of essential oils increases, this minds up a point that their possible impacts on the environment. Since, aquatic environments collect the contaminants as reservoirs for the drained of the land around or directly from several discharges, as one of the most sensitive compartments of the environment needs to be investigated. Regarding this point, the essential oils reached to the aquatic environment may have potential to impact on the non-target living organisms. Many of the safety data sheets developed for several essential oil has included the notice as "Adopt good working practices, so that the product is not released into the environment. Very toxic to aquatic organisms, may cause long-term adverse effects in the 
aquatic environment." (Anonymous, 2017b). Several studies reported deleterious effect of essential oils to aquatic organisms. There are valuable researches about biological effects of some essential oils by using different experimental designs such as mammalian cell lines (Minaiyan et al., 2011), microbial organisms or mollucidal and larvicidal activities (Rodrigues et al, 2013) and acaricid effects (Laborda et al., 2013) considering the impact on aquatic organisms. Conti et al (2014) have reported the EO extracted from aerial parts of $M$. alternifolia was evaluated for its toxicity against larvae of mosquito and estimated results were EO had a remarkable acute toxicity also towards adults of the non-target arthropod $D$. magna, with a $\mathrm{LC}_{50}=80.636$ ppm (Conti et al., 2014).

Although being used for a long time it appears that there are still gaps in the manner of environmental impacts of these natural compounds. There is no doubt that analytical chemical testing of chemicals such as pollutants give information about the quality and quantity of them but biological testing methods can give a qualitative result of the presence and strength of toxicity (Arslan et al., 2015). Algae and aquatic plants are the most important primary biomass producers in both fresh and marine waters. Accordingly, they are the most important parts of the aquatic food chain besides they are food resource and provide oxygen and shelter for many aquatic organisms (Ferreira and Graça, 2002). Algae are accepted as equally or more sensitive than animals (Ferreira and Graça, 2002) and have been widely used in toxicity tests for many purposes. Algal growth inhibition test was accepted as standard test to qualify the aquatic ecosystems by national and international organizations such OECD and EPA.

In this investigation, considering the knowledge above, Algal Growth inhibition test (OECD 2011) were applied to determine the acute toxic effects of rosemary oil (RO), wheat germ oil (WGO), tea tree oil (TTO), thyme oil (TO), eucalyptus oil (EO) and grape seed oil (GSO) and using Scenedesmus subspicatus. As it is well known the toxicity of chemicals were ranged according to species.

The aim of this research is to draw a conclusion on the effects of several natural plant oils on the primary producers in aquatic environment.

\section{MATERIALS AND METHODS}

The EOs as bioactive compounds in plants are produced as secondary metabolites (Bernhoft, 2010). The main chemical components of the essential oils produced from natural plants are low molecular weight as terpenes and terpenoids and the other of aromatic and aliphatic constituents. They can be synthesized by all parts of plants such as seed, leaves, flowers, stems, fruits etc. The essential oils are lipophilic agents and generally liquid, volatile and colourless (Bakkali et al., 2008). The essential oils such as rosemary oil (RO), tea tree oil (TTO), wheat germ Oil (WGO), grape seed oil (GSO), thyme oil (TO) and eucalyptus Oil (EO) were tested for the toxicity on phytoplankton, Scenedesmus subspicatus Chodat (regarded as syn. Desmodesmus subspicatus (Chodat) E.Hegewald \& A.Schmidt). Essential oils were kindly provided by private company (Dalan A.Ş) which produce them routinely. Stock solutions were prepared as $10 \mathrm{ppm}$ of all essential oils by dissolving the chemicals with Dimethyl sulfoxide (DMSO) (Sigma, Cat. No: 67-68-5). From the stock solutions, five experimental concentrations of five essential oils and four concentration of thyme oil (Table 1) were used after serial preliminary experiments which were started with $1-10-100$ - 1000 ppm and according to obtained results we took another serials of concentrations by dilutions from stock solutions in order to determine the acute toxicity on growth (Table 1).

Table 1. Concentrations of essential oils applied for algal growth inhibition test

\begin{tabular}{llll}
\hline Essential Oils & $\begin{array}{l}\text { Physical State } \\
\text { Appearance }\end{array}$ & $\begin{array}{l}\text { and } \\
\text { Rensity } \\
(\mathbf{g} / \mathbf{m l})(\mathbf{d})\end{array}$ & Concentrations $(\mathbf{m g} / \mathbf{L})$ \\
\hline Rosemary (RO) & Liquid & 0.8015 & $5,10,25,50,100$ \\
Tea Tree (TTO) & Liquid & 0.8043 & $12.1,20.11,48.26,100.1,201.1$ \\
Wheat Germ (WGO) & Liquid & 0.8057 & $5,10,25,50,100$ \\
Grape Seed (GSO) & Liquid & 0.7456 & $27.96,46.6,111.8,233,466$ \\
Thyme (TO) & Liquid & 0.8136 & $30.51,50.85,122.04,544.25$ \\
Eucalyptus (EO) & Liquid & 0.8446 & $22.53,33.78,45.05,56.31,67.57$ \\
\hline
\end{tabular}

Control group accompanying the experiments consisted of untreated negative controls (Filtered Fresh Water: FFW), solvent control (DMSO: $1 \mathrm{ml} / 10 \mathrm{ml}$ ) and $10^{-4} \mathrm{M} \mathrm{CdCl}_{2}$

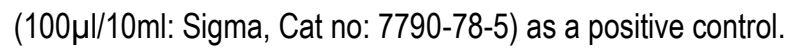

\section{Algal growth inhibition test}

The green alga Scenedesmus subspicatus was used as the test organism. Algal bioassay was carried out according to OECD 2011 standard for algal growth inhibition testing (OECD, 2011). 
The stock algal culture was maintained on algal medium according to OECD 2011 procedure. The $\mathrm{pH}$ of this medium after equilibration with air is approximately 8 . Four days before the test pre-culture was set up and incubated at $21 \pm 2{ }^{\circ} \mathrm{C}$. The initial cell concentration in the test cultures is approximately 2 $5 \times 10^{3} \mathrm{cells} / \mathrm{ml}$ for $\mathrm{S}$. subspicatus. Test tubes were held on a rocker at $100 \mathrm{rpm}$ under constant illumination at approximately 2000 lux. Cell density counted at every time point $(24,48$ and 72 hour) by Neubauer haemocytometer. The relative inhibition of growth rate was determined as reduced cell number of the treated samples in relation to controls.

The endpoints were evaluated based on cell count data and calculated growth rate $(0$ to $72 \mathrm{~h})$ as described in standard protocols (OECD, 2011) from the mean cell counts of each test series. The average specific growth rate $(\mu)$ for exponentially growing cultures were calculated as:

$$
\mu_{0-j}=\ln x_{j}-\ln x_{0} / t_{j}-t_{0}\left(\text { day }{ }^{-1}\right)
$$

$\mu_{0-j:}$ growth rate,

$\mathrm{X}_{0}$ : nominal number of cells $/ \mathrm{ml}$ at time $\mathrm{t}_{0}$,

$\mathrm{X}_{\mathrm{j}}$ : measured number of cells $/ \mathrm{ml}$ at $\mathrm{t}_{\mathrm{j}}$

to: time of first measurement of cells/ml after beginning test

$\mathrm{t}$ : time of last measurement of cells/ $/ \mathrm{ml}$ after finishing test

The percentage inhibition of the cell growth $\left(\% I_{r}\right)$ at each test substance concentration is calculated as the difference between the control growth curve $(\mu \mathrm{c})$ and the growth curve at each test substance concentration ( $\mu$ t) as:

$$
\% \mathrm{l}_{\mathrm{r}}=\mu_{\mathrm{c}}-\mu_{\mathrm{r}} / \mu_{\mathrm{c}} \times 100
$$

$\mathrm{EC}_{50}$ values were calculated from the $\%$ inhibitions by probit analyses. The Statistica- 6.0 software programme was used for probit analysis and the statistically importance of the data of growth rates were compared with controls by t-test.

\section{RESULTS}

Algal growth inhibition assays of six essential oils (RO, TTO, WGO, GSO, TO and EO) did not show severe effects on the population growth of $S$. subspicatus (Figure 1).

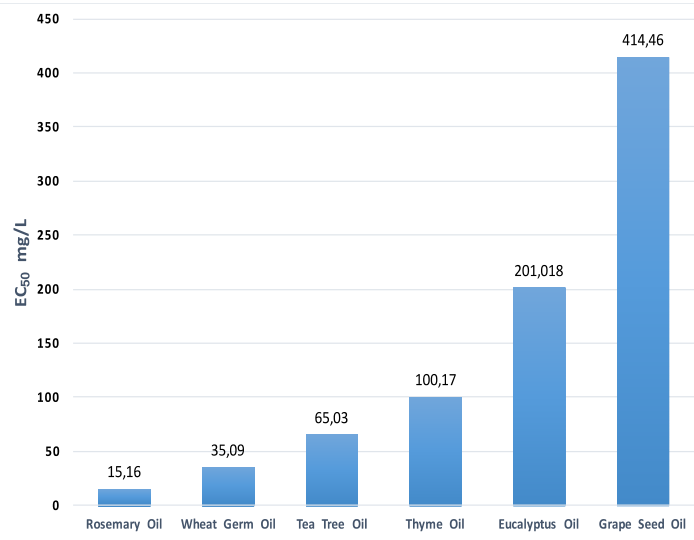

Figure 1. The $E_{50}$ values of tested essential oils
Inhibition (\%) of algae was calculated from the cell density (Figure 2). The results show that all of the essential oils used in this investigation had inhibitory effects in some degree on the growth of algae.

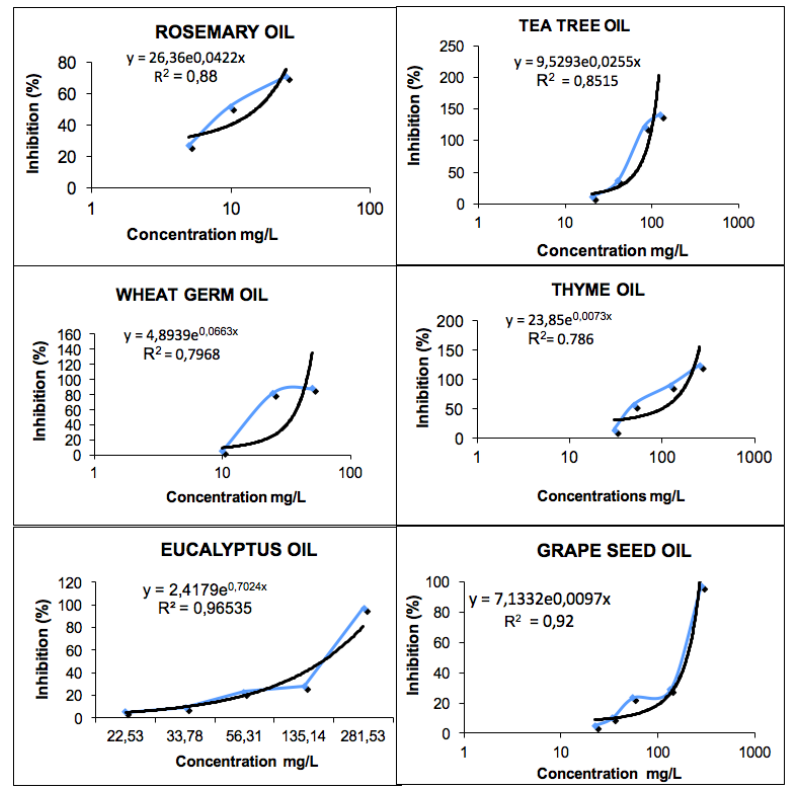

Figure 2. Algal growth inhibition of Scenedesmus subspicatus caused by some essential oils

$\mathrm{EC}_{50}$ values calculated from growth inhibitions were ranged between $15.6 \mathrm{mg} / \mathrm{L}$ (for RO) and $414.468 \mathrm{mg} / \mathrm{L}$ (for GSO). The toxicity ranking of all oils used for growth inhibition test is 15.6 $\mathrm{mg} \mathrm{RO/L}<35.09 \mathrm{mg} \mathrm{WGO/L}<65.03 \mathrm{mg}$ TTO/L $<100.17 \mathrm{mg}$ $\mathrm{TO} / \mathrm{L}<201.018 \mathrm{mg} \mathrm{EO} / \mathrm{L}<414.46 \mathrm{mg} \mathrm{GSO} / \mathrm{L}$. The $\mathrm{EC}_{50}$ of Rosemary is $15.6 \mathrm{mg} / \mathrm{L}$ which is quite high when comparing with Tea Tree Oil (35.09) but other essential oils did not show strong inhibitory effects on the growth of $S$. subspicatus. Thyme oil with having $100 \mathrm{mg} / \mathrm{L}$ ( in the border of weak toxicity to algae and grape seed oil has very high $\mathrm{EC}_{50}$ value which means it's toxicity is very low as expected due to knowledge of great antioxidant properties of grape. Wheat germ oil and tea tree oil have greater toxicity than grape oil and thyme oil but they are still not toxic as Rosemary oil. According to student test results Thyme oil and wheat germ oil show differences between concentration ( 0,019 and 0,042 respectively).

\section{DISCUSSION}

It has known that EOs have no specific cellular targets and pass thorough the cell membrane since they are lipophilic character. Cytotoxicity and membrane damage caused by some EOs have been detected in organisms in a broad of variety from bacteria, virus, fungi to mammalian cells (Bakkali et al., 2008). Environmental concerns are getting more notable in recent years and the possible impacts of chemicals produced and used for several purposes have come into prominence. Due to these reasons, there is growing interest on the assessments of the xenobiotics. To investigate the impacts of chemicals on ecosystems, toxicity assessment tests have been 
accepted as powerful tools and give powerful information about the toxicity of chemicals like persistent organic pollutants, pharmaceutically active compounds or status of sediment (Arslan and Parlak, 2007; Parlak et al., 2009; Gunduz et al., 2013) and besides mutagenic effects of chemicals can be assessed (Boyacıoğlu et al., 2007). There are quite a lot of scientific researches on adverse effects of essential oils on different groups of test organisms (Pavela, 2015). Since algae is the first trophic level in ecosystems, it has been necessary to investigate the effects of chemicals on primary producers.

In this investigation, the result show that the EOs applied had several toxic effects from non-toxic to moderate toxic level. $\mathrm{EC}_{50}$ of Rosemary oil is $15.16 \mathrm{mg} / \mathrm{L}$ and caused the highest growth inhibition while $\mathrm{EC}_{50}$ of grape seed oil has the lowest effect.

An examination on the impacts of EOs on aquatic organisms in scientific literature showed that, there are valuable papers about the pest control using some EOs. They also mentioned about the adverse impacts on non-target aquatic animals. However, in the most studies, fishes were used as non-target organisms (Govindarajan and Benelli, 2016) whereas arthropods or other organisms were rarely considered.

\section{REFERENCES}

Anonymous (2016). Guidelines on the Environmental Assessment of Natural Complex Substances (NCS). EFEO/IFRA. Version 01. 2016.

Anonymous (2017a). http://www.earthisland.org/journal/index.php/ elist/eListRead/the_environmental_impcct_of_essential_oils/

Anonymous, (2017b). http://www.esperis.it/uploads/tx_esperisproduct/ oles14.pdf

Arslan, O.C. \& Parlak, H. (2007). Embryotoxic effects of nonylphenol and octylphenol in sea urchin Arbacia lixula. Ecotoxicology,16(6), 439-444. DOI: 10.1007/s10646-007-0147-z

Arslan, Ö.Ç., Parlak, H., Boyacıŏlu, M. \& Karaaslan, M. A. (2015). Acute toxicity of several esential oils on Daphnia magna (Straus, 1816). Su Ürünleri Dergisi, 31(3), 137-143. DOI: 10.12714/egejfas.2014.31.3.04

Bakkali, F., Averbeck, S., Averbeck, D. \& Idaomar, M. (2008). Biological effects of essential oils-a review. Food and chemical toxicology,46(2), 446-475. DOI: 10.1016/j.fct.2007.09.106

Bernhoft, A. (2010). A brief review on bioactive compounds in plants. Bioactive compounds in plants-benefits and risks for man and animals: 11-17.

Boyacıoğlu, M., Arslan, Ö.Ç., Parlak, H. \& Karaaslan, M. A. (2007) Mutagenicity of nonylphenol and octylphenol using Salmonella Mutation assay. Ege Journal of Fisheries and Aquatic Sciences, 24(3-4), 299-302.

Conti, B., Flamini, G., Cioni, P.L., Ceccarini, L., Macchia, M., \& Benelli, G. (2014). Mosquitocidal essential oils: are they safe against non-target aquatic organisms? Parasitology research,113(1), 251-259. DOI:.1007/s00436-013-3651-5

Ferreira, R.C.F. \& Graça, M.A.S. (2002). A comparative study of the sensitivity of selected aquatic plants to mining effluents. Limnetica, 21(1-2), 129-134.

Geetha, R. V. \& Roy, A. (2014). Essential Oil Repellents- A Short Review. International Journal of Drug Development and Research,6(2), 20 - 27.

Gunduz, G., Parlak, H., Arslan, Ö.Ç., Boyacioglu, M. \& Karaaslan, M. A. (2013) Embryotoxic effects of Perfluorooctane Sulfonate Compounds in sea urchin Paracentrotus lividus. Fresenius Environmental Bulletin, 22(1A), 171-177.
Anonymous (2016) had reported that $\mathrm{LC}_{50}$ for thyme oil for fish acute toxicity is $6.09 \mathrm{mg} / \mathrm{L}, \mathrm{EC}_{50}$ for Daphnia magna 3.59 $\mathrm{mg} / \mathrm{L}$ and $\mathrm{EC}_{50}$ for algae $4.26 \mathrm{mg} / \mathrm{L}$. In our investigation $\mathrm{EC}_{50}$ of thyme oil on S. subspicatus calculated as $100.17 \mathrm{mg} / \mathrm{L}$ and the difference of the results may in consequence of the species which is not specified. On the other hand, Hammer et al (2006) reported a review on the toxicity of TTO and listed valuable data including $\mathrm{LC}_{50}$ for TTO components. It has also conclusions that TTO is non-toxic to rainbow trout eggs at a concentration of 1500 ppm (Hammer et al., 2006). Furthermore, LC L $_{50}$ of TTO was calculated approximately $500 \mathrm{ppm}$ in the brine shrimp assay (McCage et al, 2002). In our research EC $\mathrm{C}_{50}$ of TTO for $S$. subspicatus was $65.03 \mathrm{mg} / \mathrm{L}$ which means that the algae are more sensitive than the species in question. In conclusion, the essential oils investigated in this research, seems to be nontoxic or moderately toxic to algae $S$. subspicatus but they are less sensitive than cladoceran Daphnia.

\section{ACKNOWLEDGEMENTS}

The author would like to thank to Dalan Kimya Endustri A.S. for providing the tested essential oils and Ecotoxiclogy group of E.U Faculty of Fisheries for their great support.

Govindarajan, M. \& Benelli, G. (2016). a-Humulene and $\beta$-elemene from Syzygium zeylanicum (Myrtaceae) essential oil: highly effective and ecofriendly larvicides against Anopheles subpictus, Aedes albopictus, and Culex tritaeniorhynchus (Diptera: Culicidae). Parasitology research,115(7), 2771-2778. DOI: 10.1007/s00436-016-5025-2

Hammer, K.A., Carson, C.F., Riley, T.V., \& Nielsen, J B. (2006). A review of the toxicity of Melaleuca alternifolia (tea tree) oil. Food and chemical toxicology,44(5), 616-625. DOI: 10.1016/j.fct.2005.09.001

Laborda, R., Manzano, I., Gamón, M., Gavidia, I., Pérez-Bermúdez, P., \& Boluda, R. (2013). Effects of Rosmarinus officinalis and Salvia officinalis essential oils on Tetranychus urticae Koch (Acari: Tetranychidae). Industrial Crops and Products,48, 106-110.

DOI: 10.1016/j.indcrop.2013.04.011

McCage, C.M., Ward, S.M., Paling, C.A., Fisher, D.A., Flynn, P.J. \& McLaughlin, J. L. (2002). Development of a paw paw herbal shampoo for the removal of head lice. Phytomedicine, 9(8), 743-748. DOI: $10.1078 / 094471102321621377$

Minaiyan, M., Ghannadi, A. R., Afsharipour, M. \& Mahzouni, P. (2011). Effects of extract and essential oil of Rosmarinus officinalis $L$. on TNBS-induced colitis in rats. Research in Pharmaceutical Sciences, 6(1), 13-21.

OECD (2011), Test No. 201: Freshwater Alga and Cyanobacteria, Growth Inhibition Test, OECD Publishing, Paris.DOI: 10.1787/9789264069923-en

Parlak, H., Arslan, O.C., Boyacioglu, M. \& Karaaslan, M.A. (2009). Ekotoksikoloji. Ege Üniversitesi Su Ürünleri Fakültesi Yayınları, (79), 9-14.

Pavela, R. (2015). Essential oils for the development of eco-friendly mosquito larvicides: a review. Industrial Crops and Products, 76: 174-187. DOI: 10.1016/j.indcrop.2015.06.050

Rodrigues, K.A.D.F., Dias, C.N., do Amaral, F.M.M., Moraes, D. F., Mouchrek Filho, V. E., Andrade, E. H. A. \& Maia, J. G. S. (2013). Molluscicidal and larvicidal activities and essential oil composition of Cymbopogon winterianus. Pharmaceutical biology, 51(10), 1293-1297. DOI: 10.3109/13880209.2013.789536 